\title{
ANALYSIS OF CODE SWITCHING USED BY DEDDY CORBUZIER ON HITAM PUTIH PROGRAM IN TRANS7
}

\author{
Ari Nuryandi' ${ }^{1}$ Rizki Ridho Raharja², Hendra Husnussalam ${ }^{3}$ \\ ${ }^{1}$ IKIP SILIWANGI \\ ${ }^{2}$ IKIP SILIWANGI \\ ${ }^{3}$ IKIP SILIWANGI \\ 1ari.nuryandi@gmail.com, ${ }^{2}$ rizkiraharja0125@gmail.com, hendrahusnussalam@ikipsiliwangi.ac.id ${ }^{3}$
}

\begin{abstract}
Used two or more languages within an utterance or what linguists call code switching, fairly common especially between two of the most languages when speaking in public. The code switching often done by someone when he was talking to someone else or talking in front of the public in particular person who mastery more than one language. Deddy Corbuzier always do code switching when speaking or explain topic particular, so topic submitted more interesting.This study aims to analyze the type of code switching used by Deddy Corbuzier on Hitam Putih program in Trans7 and also describe Deddy Corbuzier do code switching based on the theory of Romaine and Hoffman. The writer also analyze the type and the reason code switching of the most dominant frequently by Deddy Corbuzier.The method in this study the writer uses qualitative descriptive and also use the case study to analyze and describe the type and the reason Deddy Corbuzier do code switching on Hitam Putih program in Trans7. A result of the research was conducted by the author shows Deddy Corbuzier more dominant code switch type of Inter-sentential switching compared other type code switching and the reason for the most dominant Deddy do code switching is quoting somebody else.
\end{abstract}

Keywords: Analysis, Code Switching, Deddy Corbuzier

\section{INTRODUCTION}

The development of technology in the world, the sooner we get any information, especially information or events in Indonesia through electronic media, one of them is television. In addition to being a medium for watching entertainment, broadcast television in Indonesia broadcast many broadcasts that educate. This program is one of the best quality about inspiration, education, and give motivation to us. Because we can know, we can also understand about people out side or arround us from the poor human until the rich human in Indonesia.

Hitam Putih program on Trans7 it's very simple and very nice where the host Deddy Corbuzier present one of story about something, someone that interest from Indonesia like our life, our occupation, our education, our culture, our habits and many more that we can talk here together. Deddy said that this program nothing lies but this is true and really happen in our life especially in Indonesia. Deddy said to audience that tv show can make one of learning for us in our life because that talk show how to present one of story and how to make that very important and all audience to feeling that. Sometimes we can hear and see how can host talking with the guest in different language, like English language. So make audience sometimes not understand what that he say, but Deddy always translate to Indonesia language to make audience more 
understand. We may often hear bilingual people switch their language into or code switching. According to (L.Bloomfield, 1935) Bilingualism as the native like control of two languages. Usually the people mastered more language like Deddy Corbuzier always do code switching when speaking in the public. Code switching is a conversional strategy, the function of which is to express social meanings" (Gumperz, 1983).

The writer can conclude that code switching is worth analyzing because it is a phenomenon that influences our community today. So, the purpose of this research is to find out the types and reasons of code switching used by Deddy Corbuzier and the dominant type of code switching used by him of Hitam Putih program on Trans7.

According to (Spolsky, 1998) defines bilingual is a person who has some functional ability in second language. That phenomenon usually called code switching in sociolinguistics. Cited by Romaine in (Faiz Ahmad, 2016) code switching can be defined as the use of more than one language, variety, style by a speaker within a utterance or discourse, and between different interlocutors or situation. Code switching occurs in bilingual and multilingual community when a person switches from one language, variety, or dialect to another one. Romaine in (Afina, 2016) States that there are three types of code switching, that is :

1. Intra-sentential switching

Intra-sentential code switching concerns alternation that occurs a sentence or a clause boundary. Sometimes mixing within word boundaries. Intra-sentential code switching occurs within sentence or clause or word or phrase. Intra-sentential code switching is the code switch that occurs in a sentence or clause. Sometimes mixed in word boundaries. This type of code switch is usually done from a language that is considered foreign to used daily language.

2. Inter-sentential switching

Appel \& Muysken in (Afina, 2016) stated that inter-sentential codes switching is the code switch that involves the movement of the language into another language between sentences. This type of code change is usually marked starting from a language that is often used and then switching to a foreign language. Inter-sentential switching can work to emphasize the point created in other languages in the conversation.

3. Tag Switching

Tag Switching are insertion of words in other languages. For example someone who daily uses the Indonesian language and then inserted the English words when he spoke.

According to (Hoffman, 1992) there are a number of reasons for bilingual person to switch their language that is talking about a particular topic, quoting somebody else, showing emphaty about something, interjection, repetition used for clarification, intention of clarifying the speech content for interlocutor, and expressing group identity.

\section{METHOD}

According Sink in (Kaswan, 2017) Method is a style of conducting a research work which is determined by the nature of the problem.The research method in this research the writer use Qualitative method, because it analyses the data in the form of utterances descriptively. The Qualitative research is used to describe and analyze code switching used by Deddy Corbuzier of Hitam Putih pogram on Trans7. 
Research design of the research, the writer use case study. According to Mitchel in (Rhee, 2004) case study as a detailed examination of an event (or series of related events) which the analyst believes exhibits (or exhibits) the operation of some identified general theoretical principles. The case study is intended to study intensively on the background of the current state of affairs and the position of an ongoing event, as well as the environmental interaction of a particular social unit.Case study is used to describe and analyze code switching used by Deddy Corbuzier of Hitam Putih Program on Trans7. The writer analyzed the type of code switching used by Deddy Corbuzier in Hitam Putih Program based on data obtained from You tube. In addition the writer analyzed the reason Deddy did the code switching.

The writer used human instrument in this research because writer the key instrument who actively and directly in data collection and data analysis. In qualitative research, the research instrument,is researchers themselves. In other words, the research tool is the researcher himself. Accordig to (Sugiyono, 2006) mentions the role of researchers as key instruments in the process of qualitative research if we look at the instruments in qualitative research.

Related instruments used by researchers to collect data is Human Instrument. The writer made several steps in collecting data. Firstly, the writer opened you tube on the web site. Secondly, the writer searched for video Deddy Corbuzier of Hitan Putih program on Trans7. Thirdly, the writer choose and identified some video Deddy Corbuzier of Hitam Putih program on Trans 7 and then downloaded about 10 videos from you tube. Fourthly, the writer watched the videos and listened to and understood the topic of each episode. Fifthly, the writer tries to transcribe the utterances and also select, and classified the data. Finally, the writer arranges the data systematically in accordance with the research questions.

To analyze data the writer use several steps. The writer choose Deddy corbuzier videos that often do code switching. And Then, the writer identified every Deddy Corbuzier doing code switching and making notes. After that, classify the data obtained in several categories according to the purpose of research that is the type of code switching and reasons Deddy Corbuzier do code switching. Finally, identify the most type of code switch that Deddy Corbuzier often do and make conclusion based on the data that has been analyzed.

\section{RESULTS AND DISCUSSION}

\section{Results}

The result of analysis code switching used by Deddy Corbuzier is present in table . The following writer serve in two tables, that is :

TABEL 1. The result of analysis type code switching used by DeddyCorbuzier 


\begin{tabular}{|l|l|l|l|}
\hline VIDEO & $\begin{array}{l}\text { Intra Sentential } \\
\text { Switching }\end{array}$ & $\begin{array}{l}\text { Inter-Sentential } \\
\text { Switching }\end{array}$ & Tag Switching \\
\hline Data 1, & Data 10 and Data 10.1 & Data 10.2, Data 1, Data & Data 9 and Data 10.4 \\
\hline Data 2, & & & \\
\hline Data 3, & & & \\
\hline Data 4, & & & \\
\hline Data 5, & & & \\
\hline Data 6, & & & \\
\hline Data 7, & & & \\
\hline Data 8, & & & \\
\hline Data 9, and & & & \\
\hline Data 10 & & & \\
\hline
\end{tabular}

TABEL $2 \& 3$. The result of analysis the reasons DeddyCorbuzier does code switching

TABEL 2.

\begin{tabular}{|l|l|l|l|l|}
\hline VIDEO & $\begin{array}{l}\text { Talking about } \\
\text { a Particular Topic }\end{array}$ & $\begin{array}{l}\text { Quoting Somebody } \\
\text { Else }\end{array}$ & $\begin{array}{l}\text { Showing Emphaty } \\
\text { about Something }\end{array}$ & Interjection \\
\hline Data 1 & Data 8 & Data 2, Data 3 & Data 7.1 and data 1 & Data 3 and data 10.4 \\
\hline Data 2 & & and Data 7 & & \\
\hline Data 3 & & & & \\
\hline Data 4 & & & & \\
\hline Data 5 & & & & \\
\hline Data 6 & & & & \\
\hline Data 7 & & & & \\
\hline Data 8 & & & & \\
\hline Data 9 & & & & \\
\hline Data 10 & & & & \\
\hline
\end{tabular}

TABEL 3.

\begin{tabular}{|l|l|l|l|l|}
\hline VIDEO & $\begin{array}{l}\text { Repetition used } \\
\text { for clarification }\end{array}$ & \multicolumn{2}{|l|}{$\begin{array}{l}\text { Intention of clarifying } \\
\text { the speech content for interlocutor }\end{array}$} & $\begin{array}{l}\text { Expressing group } \\
\text { identity }\end{array}$ \\
\hline Data 1 & Data 4 & Data 10.5 and Data 5 & & Data 6 and Data 9.1 \\
\hline Data 2 & & & & \\
\hline Data 3 & & & & \\
\hline Data 4 & & & & \\
\hline Data 5 & & & & \\
\hline Data 6 & & & & \\
\hline Data 7 & & & & \\
\hline Data 8 & & & & \\
\hline Data 9 & & & & \\
\hline Data 10 & & & & \\
\hline
\end{tabular}

The tables are the result of analyzing the type and reason of Deddy Corbuziers' code switching. The results obtained from analyzing 10 videos that the writer get from youtube. Table 1 describes the type of code switching used by Deddy corbuzier. From 10 video Deddy is two times performing intra-sentential switching that is data 10 and 10.1, 4 times inter-sentential 
switching that is data 10.2 , data 1 , data 4 and data 10.3 and twice does tag switching that is data 9 and 10.4. Table 2 explains the reasons Deddy corbuzier does code switching. From the 10 videos the most dominant reason Deddy Corbuzier doing code switching is quoting somebody else.

\section{Discussion}

After analyzed and classified the data based on the types and the reason do code switching, it is clear that Deddy Corbuzier utterances show types and the reason do code switching.

There are three types of code switching found in this study : inter-sentential switching, intrasentential switching, and tag switching by Romaine in (Afina, 2016)

1. Intra-sentential switching :

Example 1 / Data 10

"I will come back to hitam putih"

The words " I will come back " as the English word are mixed with Indonesia in sentence. So The sentence of example 1 / data 10 above is intra-sentential.

Example 2 / Data 10.1

"So you want make you need to learn English, seperti itu"?

The sentence "So you want make need to learn English" as the English sentence are mixed with Indonesia "seperti itu" as verification about something. So the sentence of example 1 / Data 10.1 above is intra-sentential.

2. Inter-Sentential :

Example 1/ Data 1

"Mereka juga punya acara sendiri di Trans7 15 Juni hari sabtu jam 9 pagi judulnya JKT 48 mission.

When Deddy Corbuzier said the title of the film he switched code from indonesia to English. Mereka juga punya acara sendiri di Trans7 15 Juni hari Sabtu jam 09.00 WIB as the Indonesia sentence are mixed English "JKT48 mission". So the sentence of example 1/ Data 5 above is Inter-Sentential.

Example 2 / Data 10.2

"Padahal itu British, dari mana kamu belajar itu "?

When Deddy Corbuzier said the word "british" he switched to foreign language. So the sentence is inter-sentential.

Example 3 /Data 4

"Karena dengan profokasi itu sengaja orang-orang menyebarkan berita informasi hoax". Example 4 / Data 10.3

"Apa yang loe dapat dari viral"?

The sentence of example 3 and 4 is Inter-sentential because Deddy switched from Indonesia to English.

3. Tag Switching :

Example 1/Data 9

"Kalau kita kan berbicara tentang behavior yang diguilt sama humanity because your behavior seperti itu"?

Example 2 / Data 10.4

"Berarti loe habis ini dapat job banyak dubbing film yah"? 
The sentence of example 1 and 2 is tag witching because Deddy insertion of a tag in one language into utterance which is otherwise entirely in other language.

According to (Hoffman, 1992) there are a number of reasons for bilingual person to switch their language that is :

1) Talking about a particular topic:

Example 1 / Data 8

"Pendidikan penting, harus pendidikan harus, you will do that also. Banyak orang mengatakan that's never to all to you try thing"

From the data above is data 8 . The writer analyzed Deddy Corbuzier when explain a topic. When he explains the topic he sometimes switches code to English, for example from data 8 Deddy Corbuzier explains the importance of education with more than one language. When explaining something sometimes we have our own thinking and the way of delivery is different based on the knowledge .

2) Quoting somebody else :

Example 1 / Data 2

"Make the rest of your life,

Become the best of your life"

Example 2 / Data 3

"Don't limit yourself"

Example 3 / Data 7

"Find yourself and be that"

From the data above are data 2, 3 and 7. The writer analyzed every last episode Hitam Putih Deddy always gives a quote. When giving a quote He always switches the code to English and He always explains the quote with more than one language. So when we hear it always touch the heart, amazed and make us motivated. According to (Hoffman, 1992) suggested that "people sometimes like to quote a famous expression or sying of some well-known figures".

3) showing emphaty about something (express solidarity ):

Example 1/ Data 7.1

"Jono, thank you for coming here "

Example 2 / Data 1

"the amazing"

From the data above. The writer analyzed when Deddy express his feelings to others. Sometimes, he switch code to English for example in data 7.1 and 1. He expressed his gratitude to Jono using English. In data 1, he express his feelings of admiration using English.

4) interjection (inserting sentence filler or sentence connectors ):

Example 1/ Data 10.4

"Okay, kalau begitu silahkan perform sekarang”!

Example 2 / Data 3

"So for now hidup kita tidak panjang" 
Deddy Corbuzier always inserts English when he speaks. For example in data 10.4 and data 3, he uses interjection in English is okay and so for now. Of course, a lot of interjection are always used by Deddy on the sidelines of the conversation, because we know Deddy Corbuzier mastered the English language. Not only Deddy anyone who knows English, Sometimes, he insert sentence filler or sentence connector.

5) Repetition used for clarification:

Example 1 / Data 4

"Hoax, kamu tahu hoax ? Hoax adalah berita yang dibuat-buat"

From the data above. The writer analyzed Deddy Corbuzier repetitions used for clarification. For the example in data 4 , he repetition "hoax" for clarification.

6) Intention of clarifying the speech content for interlocutor :

Example 1/ Data 10.5

"So, you want make you need to learn English "?

Example 3 / Data 5

"Mungkin saya akan tanyanya seperti ini, satu pertanyaan why"?

From the data above. The writer analyzed Deddy Corbuzier intention of clarifying the speech content for interlocutor when he speaks. For the example In data 10.5 and 5 he ask for clarification something by using English.

7) Expressing group identity :

Example 1 / Data 9

"Saya dulu itu, dari dulu ng'fans. I think that is amazing group"

Example 2 / Data 8.1

"and thus, maybe i don't care about that "

From the data above, writer analyzed Deddy corbuzier when he expresses his feelings a group identity. In data 9 he expresses his admiration to a group. In data 8.1 he expresses no regard to a group. When we express a group, we sometimes uses other languages to be more impressed are very animated including Deddy Corbuzier.

\section{CONCLUSION}

Related to the title of this research conducted by the researcher is the analysis of code switching used by Deddy Corbuzier of Hitam Putih in Trans 7 and find out the types and reasons of code switching used by Deddy Corbuzier and the dominant type of codeswitching. The researcher got some conclusions. That is, First Deddy corbuzier mastered English, proved he always use two languages namely Indonesia and English when become host on Hitam Putih shows, especially when he arrives foreign guest star. Second, the types of code switching by Deddy corbuzier based on Romaine in (Afina, 2016) are intra-sentential switching, inter-sentential switching and tag switching. The most type is Inter-sentential switching. Because he always do a lot of code switching from Indonesia to English. Third, there are seven reasons Deddy Corbuzier did the code change based on (Hoffman, 1992) that is talking about a particular topic, quoting somebody else, showing emphaty about something, interjection, repetition used for clarification, introduction of clarifying the speech content for interlocutor, and expressing group identity. The most dominant reason is quoting somebody else, because at the end of the event Hitam Putih program, Deddy Corbuzier always quoting somebody else. 


\section{ACKNOWLEDGMENTS}

Praise presence of Allah, because of Allah will can finishing this article. I say thanks a lot to my lecturer that Mr. Hendra Husnussalam that has helped and provide ideas in the manufacture this article. Don't forget to friends that has helped complete this article. The last of this article will not be interisting without sources support.

\section{REFERENCES}

Afina. (2016). Code Switching used by Kimmy Jayanti in ILook program on Net TV. Islamic University Malang.

Faiz Ahmad. (2016). Code Switching used by Sacha Stevenson in Tonight Show and Sarah Sechan on Net TV. Maulana Malik Ibrahim Islamic University.

Gumperz. (1983). Directions in Sociolinguistic. Oxford: Blackwell.

Hoffman. (1992). An Introduction to Linguistics. Essex: Pearson Education.

Kaswan. (2017). Metode dan Teknik Penulisan Karya Ilmiah. Cimahi: IKIP Siliwangi.

Bloomfield. (1935). Language. London: Allen \& Unwin.

Rhee. (2004). The EPO Chain in Relatioships Management:a case study of a goverment organization. University of Maryland.

Spolsky. (1998). Sociolinguistic. Oxford: Blackwell.

Sugiyono. (2006). Metode Penelitian Kuantitatif, Kualitatif dan R\&D. Bandung: Alfabeta. 